P-ISSN $2580-7781$

E-ISSN 2615 - 3238

\title{
FUNGSI BUKU TANAH DESA SEBAGAI LANDASAN YURIDIS AWAL ALAT BUKTI HAK KEPEMILIKAN ATAS TANAH
}

\section{THE FUNCTION OF THE VILLAGE LAND BOOK AS THE INITIAL JURISDICTIONAL EVIDENCE TOOL OF LAND OWNERSHIP RIGHTS}

\author{
Tedjo Asmo Sugeng \\ Fakultas Hukum, Universitas Abdurachman Salaeh Situbondo \\ Email : myibrahim0710028202@gmail.com
}

\begin{abstract}
ABSTRAK
Pengakuan Kepemilikan Hak Atas Tanah, dimanapun tanah itu berada, berapapun luas tanah dan batas-batasnya serta siapapun pemiliknya maka akan selalu ada dan tercatat dalam riwayat tanah pada catatan Buku Tanah Desa, yang lebih dikenal ditiap-tiap Kantor Desa/Kantor Kelurahan yaitu dengan sebutan Buku Letter C Desa dan Buku Kerawangan Desa. Kedua Buku Tanah Desa tersebut sudah ada pada Zaman India-Belanda dan sampai sekarang tetap dipakai sebagai Dokumen Negara, yang disimpan ditiap-tiap Kantor Desa / Kantor Kelurahan. Kedua Buku Tanah Desa tersebut selalu berdampingan karena saling melengkapi. Sebelum berlakunya Undang-Undang Pokok Agraria (UUPA) setiap terjadinya perubahan hak milik atas tanah / peralihan hak milik dari pemegang hak kepada pihak lain, baik peralihan secara hibah, wasiat, warisan atau jual beli, dulunya pada saat itu selalu dilakukan dihadapan Kepala desa. Bilamana ada perubahan hak milik atas tanah karena ada peralihan hak milik dari pemegang hak kepada pihak lain, maka dalam Buku Letter C Desa status pemiliknya dan sebab-sebab perubahan akan dicatat dan dirubah atas nama pemilik baru dan dalam Buku Kerawangan Desa akan dicatat ulang Nomor Persil pemilik baru. Buku Letter C Desa memuat datadata yuridis yaitu tentang status pemilik tanah yang menunjuk pada subjek hukumnya, sedangkan uraian mengenai objek tanah tercatat dalam riwayat tanah pada Buku Kerawangan Desa, yang memuat uraian lokasi / letak tanah, petakpetak tanah, luas tanah, batas-batas tanah dan nomor pajak. Sebelum berlakunya UUPA para pemilik tanah waktu itu bagi pemegang Surat Kutipan Letter C Desa dan pemegang Surat Koher Petok D dianggap sebagai pemilik tanah. Penelitian ini menjelaskan tentang bagaimana fungsi Buku Letter C Desa dalam kaitannya dengan Buku Kerawangan Desa. Dan kedudukan Surat Kutipan Letter C Desa atau Surat Koher Petok D sebagai alat bukti awal kepemilikan hak atas tanah.
\end{abstract}

Kata Kunci : Buku Letter C Desa, Buku Kerawangan Desa.

\begin{abstract}
Recognition of Ownership of Land Rights, wherever the land is located, regardless of the land area and boundaries and whoever the owner is, it will always be there and recorded in the history of the land in the Village Land Book records, which are better known in each Village Office / Kelurahan Office, namely as Village Letter C Book and Village Openwork Book. The two Village Land Books existed during the Indo-Dutch period and are still used as State Documents, which are kept in each Village Office / Kelurahan Office. The two
\end{abstract}


P-ISSN 2580 - 7781

E-ISSN 2615 - 3238

Village Land Books are always side by side because they complement each other. Prior to the enactment of the Basic Agrarian Law (UUPA), every change in ownership of land / transfer of property rights from the right holder to another party, whether transfer by grant, will, inheritance or buying and selling, was always carried out before the village head. If there is a change in ownership of the land due to a transfer of ownership rights from the right holder to another party, then in the Village Letter $C$ the status of the owner and the reasons for the change will be recorded and changed in the name of the new owner and in the Village Kerawangan Book the Persil Number will be re-recorded. the new owner. The Village Letter $C$ book contains juridical data, namely the status of the land owner which refers to the legal subject, while the description of the land object is recorded in the land history in the Village Kerawangan Book, which contains a description of the location / location of the land, land plots, land area, land boundaries and tax numbers. Prior to the enactment of the LoGA, the land owners at that time for the holders of the Village Quotation Letter $C$ and the holders of the Petok D Koher Letter were considered as land owners. This study explains how the function of the Village Letter $C$ Book in relation to the Village Kerawangan Book is. And the position of the Village Letter C Quotation or Petok $D$ Koher Letter as initial evidence of ownership of land rights.

Keywords: Village Letter C Book, Village Kerawangan Book.

\section{PENDAHULUAN}

Untuk mengetahui status tanah, siapapun pemiliknya dan dimanapun tanah itu berada serta berapapun luas tanahnya dan batas-batasnya maka atas ijin kepala desa / lurah dapat dilihat / dicek di dua Buku Tanah Desa (Buku Letter C Desa dan Buku Kerawangan Desa). (Andreas Lumme 2001 : 32 )

Buku Letter C Desa, menunjuk kepada pemilik tanah yang sebenarnya (subjeknya). Buku Kerawangan Desa, memuat uraian Buku Letter C Desa yang menunjuk pada objek tanahnya. Antara lain memuat uraian riwayat tanah, lokasi / letak tanah, petak-petak tanah, luas tanah, batas-batas tanah dan nomor persil pemilik, nomor pajak bumi.

Sebelum berlakunya UUPA pemegang hak atas tanah, istilahnya bermacammacam antara lain : Tanah-Tanah Ketitir yang dimaksud adalah pemegang haknya memegang Surat Tanah Ketitir, Tanah Rincik (pemegang haknya memegang Surat Tanah Rincik), Tanah Girik (pemegang haknya memegang Surat Tanah Girik), Tanah Letter $\mathrm{C}$ yang dimaksud adalah pemiliknya memegang Surat Kutipan Letter C Desa, Tanah Petok D yang dimaksud adalah pemegang haknya memegang Surat Koher Petok D. Bahkan sampai sekarang dimasyarakat masih 
P-ISSN 2580 - 7781

E-ISSN 2615 - 3238

diketemukan memegang Surat Kutipan Letter C Desa dan ada juga dimasyarakat yang masih memegang Surat Koher Petok D yang masih belum di sertifikat. Para pemegang hak milik atas tanah sebagaimana tersebut di atas diberi beban kewajiban membayar pajak tanah dan setelah berlakunya UUPA masih ada Buku Pajak sisa jaman dahulu yang ada ditiap-tiap Kantor Desa / Kantor Kelurahan, selain kedua Buku Tanah Desa masih ada juga Buku Register Pajak Hasil Bumi / Buku Register Pajak Bumi dan Bangunan, isinya memuat Daftar Nama-Nama Wajib Pajak.

\section{METODE PENELITIAN}

Jenis penelitian yang digunakan dalam penelitian ini yaitu penelitian hukum normatif yaitu suatu penelitian hukum yang membahas dan menganalisis dalam tataran norma, asas dan doktrin hukum. Adapun pendekatan yang digunakan dalam penelitian ini untuk menunjang jenis penelitian hukum normatif yaitu pendekatan perundang-undangan yaitu menelaah peraturan yang berkaitan dengan permasalahan hukum yang diteliti dalam hal ini peraturan terkait hukum perkawinan. Serta digunakan juga pendekatan analisis konsep hukum yaitu merujuk pada asas-asas, konsepsi, dan doktrin hukum yang berkaitan dengan permasalahan yang diteliti dalam jurnal ini.

\section{HASIL PENELITIAN DAN PEMBAHASAN}

\section{PENGERTIAN HAK MILIK ATAS TANAH MENURUT UUPA}

Mengenai pengertian hak milik ini diatur dalam pasal 20 ayat (1) UndangUndang No.5 Tahun 1960 yaitu "Hak turun-temurun terkuat dan terpenuhi yang dapat dipunyai orang atas tanah, dengan mengingat ketentuan pasal 6 UUPA". Menurut Boedi Harsono : Mengatakan bahwa pengertian "turun-temurun” artinya hak milik tanah tidak hanya dapat dipunyai oleh seseorang selama dia masih hidup, akan tetapi hak milik tersebut dapat diteruskan oleh ahli warisnya apabila pemiliknya meninggal dunia.

Kata "terkuat" mengandung pengertian bahwa hak milik itu tidak mudah dihapus bila dibandingkan dengan hak-hak lainnya serta dapat dipertahankan 
P-ISSN 2580 - 7781

E-ISSN 2615 - 3238

terhadap gangguan pihak lain. Kata "terpenuh" tersebut mengandung pengertian sebagai berikut :

a. Hak milik itu memberikan wewenang kepada pemiliknya yang paling luas jika dibandingkan dengan hak yang lainnya, tidak dapat diganggu gugat akan tetapi harus memperhatikan fungsi sosial dari tanah itu yang seperti tercantum dalam pasal 6 Undang-Undang Pokok Agraria.

b. Hak milik ini dapat menjadi hak induk dari hak-hak lain, artinya seorang pemilik tanah bisa memberikan tanah kepada pihak lain dengan hak-hak : menyewakan, membagi hasilkan, menggadaikan, menyerahkan tanah kepada orang lain dengan hak guna bangunan atau hak pakai.

c. Dilihat dari peruntukkannya hak milik sifatnya tidak terbatas,

Artinya dapat digunakan untuk usaha pertanian dan untuk bangunan, dan sebagainya.

\section{HAK ATAS TANAH MENURUT UUPA}

Sedangkan pengertian hak atas tanah menurut UUPA seperti yang tercantum dalam pasal 4 ayat (2) adalah sebagai berikut : "Hak-hak atas tanah yang dimaksud dalam ayat (1) pasal ini memberi wewenang untuk mempergunakan tanah yang bersangkutan, demikian pula tubuh bumi dan air serta ruang diatasnya sekedar diperlukan untuk kepentingan yang langsung berhubungan dengan penggunaan tanah dalam batas-batas menurut Undang-Undang ini dan peraturanperaturan hukum lain yang lebih tinggi”. (AP. Perlindungan II.2001 :206)

Berdasarkan pengertian hak atas tanah diatas, maka dapat diketahui bahwa antara pemegang hak atas tanah dengan tanah yang dikuasainya terdapat suatu hubungan, dimana hak atas tanah memberikan kewenangan kepada pemegang hak atas tanah untuk menggunakan dan mengambil manfaat dari tanah yang dikuasainya. Akan tetapi, perlu diingat meskipun pemegang hak atas tanah diberi kewenangan penuh, namun harus tetap mengingat fungsi sosial tanah seperti yang telah tercantum dalam pasal 6 UUPA. Menurut UUPA, hak atas tanah dibedakan menjadi beberapa golongan :

a. Hak atas tanah bersifat tetap yaitu hak atas tanah yang dipertahankan sepanjang Undang-Undang No. 5 Tahun 1960 tetap diberlakukan. 
P-ISSN 2580 - 7781

E-ISSN 2615 - 3238

b. Hak atas tanah yang bersifat sementara yaitu hak atas tanah yang pada hakekatnya tidak sesuai dengan jiwa hukum agraria nasional. Hak-hak tersebut diatur dalam pasal 53 UUPA yang meliputi hak gadai, hak menumpang dan hak sewa tanah pertanian.

c. Hak pengelolaan, hak ini ada setelah lahirnya Peraturan Menteri

Agraria No. 9 Tahun 1965 tentang Pelaksanaan Konversi Hak Penguasaan Tanah Negara.

\section{FUNGSI BUKU LETTER C DESA DALAM KAITANNYA DENGAN BUKU KERAWANGAN DESA}

Sebagaimana yang dikemukakan pada uraian sebelumnya bahwa pada dasarnya ada 2 (dua) macam buku administrasi pencatatan tanah di tiap-tiap Kantor Desa / Kantor Kelurahan :

a. Buku Letter C Desa

b. Buku Kerawangan Desa

Kedua buku tersebut harus ada dan harus berdampingan dan harus saling melengkapi karena Buku Letter C Desa menunjuk pada data-data kepemilikan subjek sedangkan Buku Kerawangan Desa menunjuk pada objek tanahnya yang memuat uraian :

a. Letak posisi tanah atau letak lokasi tanah

b. Luas tanah

c. Batas-batas tanah

d. Atau petak-petak tanah

e. Nomor petok

f. Nomor persil

Buku Letter C Desa adalah buku tanah yang memuat data-data kepemilikan tanah yang berisi :

a. Nama pemilik

b. Nomor urut pemilik

c. Nomor bagian persil

d. Kelas desa

e. Hal-hal menurut pajak bumi yang terdiri atas : 
P-ISSN 2580 - 7781

E-ISSN 2615 - 3238

i. Luas tanah hektar (ha) dan are (da)

ii. Nilai pajak R (rupiah) dan sen (s)

f. Sebab dan hal perubahan

g. Mengenai kepala desa yakni tanda tangan dan stempel.

Contoh :

Nama : Pemilik lama / baru

Nomor Urut Pemilik :

\begin{tabular}{|c|c|c|c|c|c|c|}
\hline \multirow{3}{*}{$\begin{array}{l}\text { Nomor dan } \\
\text { bagian persil }\end{array}$} & \multirow{3}{*}{$\begin{array}{l}\text { Kelas } \\
\text { Desa }\end{array}$} & \multicolumn{4}{|c|}{$\begin{array}{c}\text { Menurut Daerah Perijinan Pajak } \\
\text { Bumi }\end{array}$} & \multirow{3}{*}{$\begin{array}{l}\text { Sebab dan } \\
\text { perubahan }\end{array}$} \\
\hline & & \multicolumn{2}{|c|}{ Luas Tanah } & \multicolumn{2}{|c|}{ Pajak } & \\
\hline & & $\mathrm{Ha}$ & $\mathrm{Da}$ & $\mathrm{R}$ & $S$ & \\
\hline & & & & & & \\
\hline & & & & & & \\
\hline & & & & & & \\
\hline
\end{tabular}

Nama Desa, Tgl,

Mengetahui,

Kepala desa / Kelurahan

Ttd

Nama Kepala desa

Di dalam keterangan ataupun contoh diatas terdapat kata "Persil" dan kelas desa,

a) Persil adalah suatu letak tanah dalam pembagiannya atau disebut juga (blok).

Contoh :

Tanah dengan luas 1 hektar, atau tanah itu dibagi dengan berbagai bagian yang pemiliknya berbeda, luas tanahnya berbeda.

\begin{tabular}{|l|l|l|l|}
\hline Persil 1 & \multicolumn{3}{|c|}{ Persil 4 } \\
\cline { 1 - 2 } Persil 2 & Persil 5 & Persil 6 & Persil 7 \\
\hline Persil 3 & & & \\
\hline
\end{tabular}


P-ISSN 2580 - 7781

E-ISSN 2615 - 3238

b) Kelas desa adalah suatu kelas tanah biasanya dipergunakan untuk membedakan antara darat dan tanah sawah atau diantara tanah yang produktif dan non produktif ini terjadi pada saat klasiran beberapa tahun dulu.

Contoh :

1) Kelas d.I.d.II,

Adalah kelas ini digunakan untuk perumahan

2) Kelas S.I,S.II,

Adalah kelas ini digunakan untuk sawah dan pertanian.

Selanjutnya baik persil, kelas desa, luas tanah, besarnya pajak disebut di dalam Buku Letter C Desa, berarti pemilik tanah ini adalah seorang yang memiliki hak atas tanah tersebut dan berkewajiban membayar pajak.

Jadi Kedua Buku Tanah Desa tersebut dapat berfungsi sebagai Dokumen Negara yang dapat dijadikan landasan yuridis dan acuan pada setiap adanya perubahan hak kepemilikan atas tanah / peralihan hak milik dari pemegang hak kepada pihak lainnya.

\section{KEDUDUKAN SURAT LETTER C DESA DAN SURAT KOHER PETOK D SEBAGAI ALAT BUKTI AWAL KEPEMILIKAN HAK ATAS TANAH}

Kedua surat tersebut diatas sebagai alat bukti pengakuan kepemilikan hak atas tanah yang dikeluarkan oleh desa berdasarkan catatan riwayat tanah pada kedua Buku Tanah Desa :

1) Surat Letter C Desa dikeluarkan oleh desa berdasarkan kutipan dari Buku Letter C Desa yang ditanda tangani oleh Kepala desa dan berstempel desa.

2) Surat Koher Petok D dikeluarkan oleh desa yang memuat catatan hak kepemilikan berdasarkan Buku Tanah Desa yang ditanda tangani oleh Kepala desa dan disahkan oleh camat setempat.

Sebelum berlakunya UUPA pemegang hak milik atas tanah yang tercantum nama pemiliknya pada masing-masing kedua surat tersebut diatas, kedudukannya adalah sebagai pemilik tanah sehingga Surat Kutipan Letter C Desa dan Surat Koher Petok D (yang belum di sertifikat) dapat dijadikan sebagai alat bukti awal dalam pengajuan permohonan Sertifikat Tanah pada Kantor Badan Pertanahan, 
P-ISSN 2580 - 7781

E-ISSN 2615 - 3238

sepanjang tidak ada pembuktian alat bukti lainnya sebagai pembanding dalam pengakuan hak milik atas tanah oleh pihak lainnya.

Syarat-syarat pengajuan permohonan sertifikat :

1. Fotokopi KTP pemohon

2. Fotokopi Kartu Keluarga pemohon

3. Membawa bukti perolehan tanah

4. Fotokopi bukti pembayaran PBB tahun terkahir

5. Fotokopi NPWP

6. Pernyataan tanah tidak sengketa dari kantor Desa.

\section{KESIMPULAN}

Semua catatan riwayat tanah dimana tanah itu berada dan siapa pemiliknya, berapapun luas tanahnya dan batas-batasnya. selalu ada dan tercatat dalam catatan riwayat tanah pada kedua Buku Tanah Desa (Buku Letter C Desa dan Buku Kerawangan Desa). Karena kedua Buku Tanah Desa tersebut merupakan Dokumen Negara yang disimpan ditiap-tiap Kantor Desa / Kantor Kelurahan, yang dapat berfungsi sebagai landasan hukum dan acuan pada setiap peralihan hak atas tanah dan sebagai alat bukti awal dalam setiap pemprosesan peralihan hak milik dari pemegang hak kepada orang / pihak lain. Sedangkan Surat Letter C Desa dan Surat Koher Petok D dibuat oleh desa berdasarkan kedua Buku Tanah Desa. Surat Kutipan Letter C Desa dikeluarkan oleh desa yang ditanda tangani oleh kepala desa dan berstempel desa dibuat berdasarkan kutipan dari Buku Letter C Desa. Dan uraian dalam Surat Kutipan Letter C Desa tercatat dalam Buku Kerawangan Desa (mengenai objek tanahnya). Surat Koher Petok D dikeluarkan oleh Kepala desa berdasarkan kedua Buku Tanah Desa yang ditanda tangani oleh kepala desa dan berstempel desa serta diketahui dan disahkan oleh camat setempat. Sehingga pemegang hak milik atas tanah yang berupa Surat Kutipan Letter C Desa atau Surat Koher Petok D adalah dapat dijadikan dasar alat bukti awal dalam pengajuan permohonan sertifikat tanah pada kantor Badan Pertanahan. 
P-ISSN 2580 - 7781

E-ISSN 2615 - 3238

\section{DAFTAR PUSTAKA}

Andreas Lumme.2001, Majalah Hukum Pro Justitia, Edisi Kedua Tahun XIX, Fakultas Hukum. Universitas Parahyangan. Bandung

AP. Perlindungan II 2001, Pendaftaran Tanah di Indonesia, Cet Pertama Mandar Maju. Bandung

Boedi Harsono. 1999, Hukum Agraria Nasional. Edisi Revisi. Djambatan. Jakarta

Undang-Undang Pokok Agraria Nomor 5 Tahun 1960 beserta aturan pelaksanaannya. 